\title{
Innovative Activity of Small Tourist Enterprises - Cooperation with Local Institutional Partners
}

\section{Marta Najda-Janoszka*}

\begin{abstract}
According to the open innovation model an effective strategy for increasing innovation and competitiveness of the region should be based on active and multilevel cooperation among operators of the local tourism business environment. It is commonly assumed that an exceptionally important role in creating a favorable environment for the cooperative practices in the region is performed by local authorities. Yet, a modest number of research findings presented in the literature indicate a rather high level of inertia of local authorities in creating appropriate conditions for tourism business development, thus putting in question the effectiveness of performed intermediary function in the process of knowledge transfer among tourist enterprises. Given the paucity of empirical evidence on effectiveness of innovation policy interventions at the regional level, this article presents the empirical findings regarding cooperation in innovation between tourist enterprises and local institutional agents.
\end{abstract}

Keywords: tourism, innovation, cooperation, institutional environment, local government.

\section{Introduction}

Competition in a spatial dimension between geographical areas is a complex phenomenon, since regions and communities compete simultaneously on different levels for residents, investors, tourists, public funds (Dziemianowicz, 2008). Local institutional bodies responsible for providing favorable conditions for sustainable economic growth of a particular community need to formulate and implement strategies enabling continuous development of the community competitive potential and its effective use while confronting other locations. Since tourism is commonly and officially recognized as one of the fastest growing economic sectors in the world and a key driver for socio-economic progress, a growing number of local authorities turn towards tourism industry in their search for the most promising direction of economic growth. However, tourism business, although highly dynamic, is also

\footnotetext{
* Marta Najda-Janoszka, Ph.D., Department of Management in Tourism, Jagiellonian University in Krakow, ul. S. Łojasiewicza 4, Krakow, Poland, e-mail: marta.najda-janoszka@uj.edu.pl.
} 
characterized by an exceptionally intense competitive pressures. According to subject literature shaping and maintaining competitive advantages of tourism enterprises should be based on considerably high and stable innovation rate (Bednarczyk, 2006; Hjalager, 2002; Sundbo, Orfila-Sintes and Sørensen, 2007; Weiermair, 2006). Yet, the observed level of innovation in tourism is rather low and the findings indicate a weak propensity of tourist enterprises to cooperate in innovation with operators of local tourism business environment (Bednarczyk 2013; Camison and Monfort-Mir, 2012; Sundbo et al. 2007).

Since the research results presented in the literature confirm the existence of a direct correlation between the cooperative activity of enterprises and their level of innovativeness (Trigo and Vence, 2012), there is a great need for an efficient intermediary agent to enhance the cooperative capability and further the innovation rate of tourist enterprises. An emerging literature on tourism management ascribes this intermediary function to local institutional bodies conceptualized as integral co-producers of the value in the tourism innovation process. However, as pointed by Hjalager (2010) "the literature on tourism innovation policies is mainly conceptual or prescriptive, and there is still only vague evidence of its effects and effectiveness". Thus, aiming at filling the cognitive gap, this article presents the empirical findings regarding inefficiencies in cooperation in innovation between tourist enterprises and local institutional agents.

\section{Institutional support for innovations in tourism}

The role of the local governmental bodies is an emerging field of study within tourism research (Hjalager, 2010, p. 8). The literature provides a growing number of concepts of the multidirectional impact of institutional agents on the growth and innovation of tourism sector. Authors indicate the significant potential of local governments by discussing the manifold functions of them raging from formal policy-making, collecting and redistributing funds, to active promoting, developing favorable conditions for tourism growth, facilitating and coordinating collaborative initiatives concerning local sustainable development (Keller, 2006, Decelle, 2006, Weiermair, 2006, Bednarczyk, 2013; Najda-Janoszka, 2010). It becomes a widely applied approach to conceptualize local governments as integral and actively involved co-producers of the value in the process of tourism innovation (Bednarczyk, 2013; Hjalager, 2010, Weiermar, 2006). Nevertheless, according to research results presented in the literature innovation behavior of tourist enterprises indicates a minor engagement of external actors in the innovation process and very weak or even non-existent innovation systems in tourism industry (Sundbo et al. 2007, p. 90-91). The high level of imitability of tourist 
innovations due to their unsophisticated nature and difficulties with effective protection of created value leads to the proliferation of free-rider behavior and thus rather competitive than cooperative attitudes in tourism sector (Najda-Janoszka, 2013a, 2013b; Sundbo et al., 2007; Hjalager, 2002; Nordin, 2003). At the same time, it has been emphasized that in tourism successful development and implementation of original product innovations (new to the market) require effective cooperation with providers of complementary services (Keller, 2006, p. 38).

Highly specific projects call for complex collaborative structures that incur high transaction costs unaffordable for micro and small enterprises that dominate tourism industry (Keller, 2006, p. 38). According to Community Innovation Survey 2010 the most severely experienced barriers hampering innovation among tourist enterprises are the lack of funds for costly innovative activities together with the lack of qualified personnel crucial for setting social bonds that enable networking. Hence, small tourist enterprises show limited capabilities to apply professional approach to generating benefits from the networks (Sundbo et al., 2007, p. 101). Taking into account the nature of the tourism business characterized by exceptional complementariness and interdependence (Camison and Monfort-Mir 2012) together with lack of capabilities to cooperate on one hand and a significant increase in the importance of cooperation as the basis of economic growth on the other, there is a great need for stimulation and support of cooperative initiatives in tourism destinations in order to develop institutionalized systems of tourism innovation (Sundbo et al., 2007; Weiermair, 2006). Thus, many authors underline the need for active role of institutional bodies in providing support for cooperative initiatives and not for individual firms or outright innovations that often lead to rather rent-seeking behavior than more intense innovative activity (Weiermair, 2006; Keller, 2006; Decelle, 2006). According to Weiermair (2006) government's supportive engagement should be exercised in a form of a facilitator or an incubator for generating and developing complex, commondestination innovative ideas further implemented by private sector, bearing in mind that the local authority does not create innovations but provides favorable incentive system for developing innovations (Keller, 2006, p. 17). Hence, local authorities should encourage tourist enterprises to innovate on the basis of cooperation in networked structures consisting of public and private entities (Weiermair, 2006). Reorientation of local government in the strategy to build social and institutional networks should enable developing a friendly and attractive environment for companies, their establishment, development, and relocation (Blakely and Leigh, 2009, p. 95).

The issue of institutional support for the development of tourism enterprises at the local level has been the subject of a research project 
carried out by the research team of the Department of Management in Tourism at the Jagiellonian University in Krakow in years 2008-2009** as part of a longitudinal study of competitiveness of micro, small and medium sized tourist enterprises in Poland run by M. Bednarczyk since 2003. According to the concept of the research formulated by M. Bednarczyk (2011) the content of activities performed by the local institutional bodies determines the three external leverages of competitiveness of tourist enterprises defined as:

- Interaction - concerning common, joint actions of tourist firms and local authorities focused on creating favorable conditions for the development of tourism business in a particular region.

- Co-creation - encompassing the engagement of tourist enterprises in developing and implementing the strategies of tourism growth in communities and the impact of information systems implemented by local authorities on the local conditions for tourism business development.

- Collaboration - reflecting the quality of the cooperation among tourist enterprises, institutional bodies and local communities.

Defined levers were evaluated according to the level of the inertia exhibited by the local institutional bodies ranging from 0 (the lowest level) up to 4 (the highest level).

Table 1. The inertia of external leverages of competitiveness

\begin{tabular}{cc}
\hline External leverage of competitiveness & Inertia \\
\hline Interaction & 3.08 \\
Co-creation & 2.11 \\
Collaboration & 2.62 \\
\hline
\end{tabular}

Source: Najda-Janoszka (2010), p. 53.

The obtained overall picture reflected rather marginal utilization of the supportive potential of local authorities in developing a nourishing environment for tourism business growth. Almost half of the surveyed tourist enterprises (accommodation and food services, travel agencies and tour operator services) indicated lack of any activity assumed to be performed by the local governments. Hence, during the three-year period covered by the research there was no significant improvement in the indicated levels of inertia for defined external levers of competitiveness (Najda-Janoszka, 2010). Due to the key role of local institutional bodies in the knowledge

\footnotetext{
** Research Project "Entrepreneurship in the tourist economy based on knowledge" lead by prof. M. Bednarczyk, carried out by the research team of the Department of Management in Tourism at the Jagiellonian University in Krakow, Poland in years 2008-2009, financed by the Ministry of Science and Higher Education of Poland - project number N N 1153730 33.
}

Entrepreneurship in Tourism and Sport, M. Bednarczyk, J. Gancarczyk (Eds.) 
transfer process in tourism industry the consequences of such high inertia are expected to be pervasive concerning the tourist innovation process.

\section{Research methodology}

The thorough investigation of competitive potential of tourism business in Poland during the previous research projects (Bednarczyk, 2011, Bednarczyk, 2006) provided a conceptual ground for exploring innovation process in tourism from the open innovation perspective, assuming that the synergy resulting from cooperation of the key regional stakeholders at all stages of the innovation process produces the added value within the regional tourism innovation chain (Bednarczyk, 2013, p. 17). Hence, in years $2010-2013$ the research team of Department of Management in Tourism at the Jagiellonian University led by Professor M. Bednarczyk conducted a complex study, aiming at developing conceptual and methodological foundations for the integrated management of the innovative value chain at the regional level (Bednarczyk, 2013 , p. 17). The project was recommended and financed by the Ministry of Science and Higher Education in Poland (Project No. N 115321 339).

The concept of the innovative value chain of the regional tourism (IVCRT) developed by Bednarczyk (2013) provides a methodological basis enabling departure from the common practice of applying to the service sector models of the innovation process not suitable to its specifics since they were developed and dedicated to the manufacturing industries. The research model (Figure 1) has been formulated following the logic of the entrepreneurial view of tourism business and its internal (management) and external (environment, local and regional) sources of innovation capacity (Bednarczyk, 2011, pp. 65-74). 


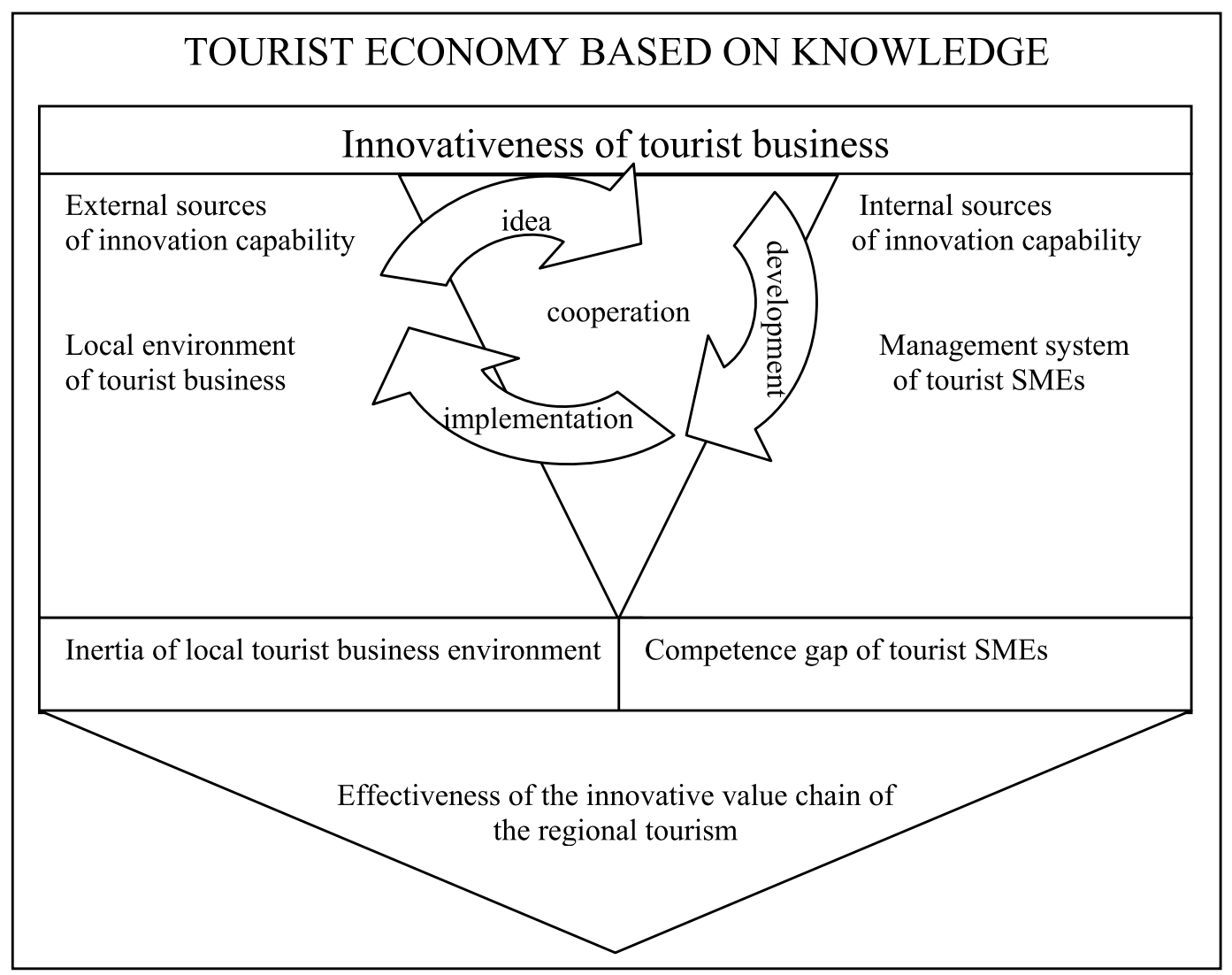

Figure 1. Research model of managing the innovative value chain of the regional tourism

Source: Bednarczyk (2013), p. 18.

The core of the research model is the overlap of three dimensions, namely "the efficient management of tourist enterprises, the quality of the local business environment (institutional and social) and the local platform for cooperation in order to make the best use of emerging synergies" (Bednarczyk, 2013, p 19). Consequently, the stakeholders of the regional innovation process were grouped into five categories: micro, small and medium-sized tourist enterprises (MSMTEs), units of the economic selfgovernment, local government bodies, the customers of the tourism industry, residents of communities where tourism is an important element of economic life. Empirical studies were conducted in 2012 in the southern region of Poland (NUTS 1), selected on the basis of tourist attractiveness index and the development status of regional innovation strategies. The structured questionnaires were directed to all five categories of stakeholders. In order to maintain continuity of the long-term monitoring of the competitive potential of tourism enterprises carried out by the research team of Department of Management in Tourism run by M. Bednarczyk, the MSMTEs category 
included enterprises performing business activities identified in the HORECA. The formulated by M. Bednarczyk concept of IVCRT has been empirically verified in the study sample consisting of (Bednarczyk, 2013, p 32):

- 55 MSMTEs,

- 275 units of local government,

- 11 units of economic self-government,

- 300 customers of tourist business,

- 389 community residents.

The resulting frequencies were sufficient for carrying out an analysis and reasoning in line with methodological assumptions of the research project. According to the logic of developed research model nine critical tasks of the IVCRT have been defined and further thoroughly verified during empirical research. This paper presents and discusses the issues concerning cooperation between tourist enterprises and local institutional bodies in the innovation process. The content of this complex problem has been included in six out of nine critical tasks of the IVCRT:

Area: External sources of innovation capabilities defined by the local tourism business environment:

- Ensuring efficient and effective exchange of information used in the innovation process between the local business environment and business tourism destinations.

- Preparing and providing access to creative and skilled personnel capable of carrying out innovative activities.

- Providing technological support to the info-space, in which the phases of the innovation process are being carried out.

- Providing financial support and access to sources of financial capital for activities performed in subsequent phases of the innovation process

- Area: Synergy of external and internal sources of innovation capacity:

- The cooperation between local tourist business environment and MSMTEs at all stages of the innovation process.

- Area: Efficiency of IVCRT

- Generating added value through innovation by individual stakeholders in the region.

\section{Results and discussion}

Most tourist enterprises, due to their reduced dimension, often face the challenge of reaching an optimum rate of innovation being unable to provide a strategically necessary continuity of innovative activity (Camison and Monfort-Mir ,2012). Resulting diseconomies of scale usually have a direct impact on the profitability of investments made at each phase of innovation 
process, and therefore affect the propensity to engage resources to innovative ventures (Camison and Monfort-Mir, 2012). Thus, in majority of surveyed tourist enterprises, generating ideas for innovations is based more often on information collected individually by particular employees than through a more complex market research procedure and systematic monitoring and analysis (see Figure 2). At this essential moment of interaction between internal and external innovation capacity tourist enterprises rely predominantly on internally accumulated knowledge acquired rather irregularly from customers, competitors and suppliers (Najda-Janoszka, 2013a).

While a marginal interest in information provided by institutions performing basic research has rather been expected, bearing in mind the specific nature of value creation process in tourism business, the fact that local community institutions are considered of minor importance as sources of information for innovation is somehow puzzling, given the proclaimed intermediary function of those institutions in the knowledge transfer process within the tourism industry. Nevertheless, obtained results are consistent with the CIS 2010, in which local institutional bodies belong to the least important sources of information for innovations introduced in tourism. The unsatisfactory (barely approaching the average level) evaluation of the existing information exchange in the local tourism environment made by surveyed tourist enterprises (Batorski, 2013), directly corresponds with the arguments concerning possible penalties resulting from the malfunctioning of the intermediary institutions (Hjalager 2002, Camison and Monfort-Mir, 2012).

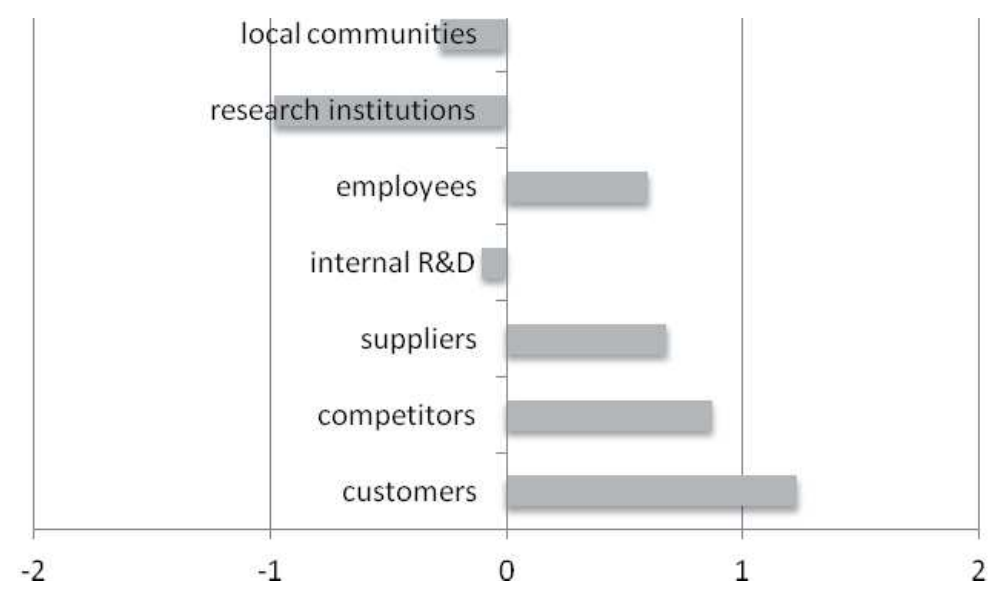

least important source

most important source

Figure 2. Important sources of information for innovation 
Since value creation in tourism is to a large extent determined by spatial assets, the relational embeddedness in the local environment is regarded essential for the successful innovation process. In the research sample the strongest and most stable business relations link tourist firms with customers and suppliers, yet other agents on the local arena are evidently marginalized (Kopera, 2013). Almost every second respondent indicates weak or very weak relations with local community institutions (Kopera, 2013). The observed tendency to ignore the informative and relational potential of local community bodies does not allow for an effective improvement of provided content toward the needs of tourism innovation. Moreover, an extensive, dense network of relationships is commonly assumed to constitute a fertile ground for cooperative initiatives and ventures. The exhibited paucity of relationship linkages with local institutions suggests a weak disposition toward cooperation with those bodies. The following Figures 3 and 4 empirically test this supposition.

The findings presented in Figure 3 indicate a very little level of involvement in cooperation with tourist enterprises exhibited by local institutional bodies across all supportive activities they perform (Kurleto, Chudzik and Marszałek, 2013). On the contrary the majority of surveyed firms declare a multiple experience in cooperation in the area of supply and promotion, which coincides with the above-mentioned distribution of maintained important business relationships. In case of local community institutions, neither of the listed lines of actions reaches the average level of cooperative engagement, even those requiring collaboration by definition, i.e. facilitating cooperation among tourist businesses, fining business partners, developing new regional tourist products (Kurleto et al., 2013). 
Improving quality of tourist services

Developing new local and/or regional tourist products

Planning and implementing marketing projects on local and/or regional level

Designing and implementing complex IT solutions

Facilitating cooperation among entities of tourism industry

Designing and impementing environmental investments

Finding business partners

Aquisition of specialized human resources

Providing knowledge and sharing best practices for raising funds to finance development ventures

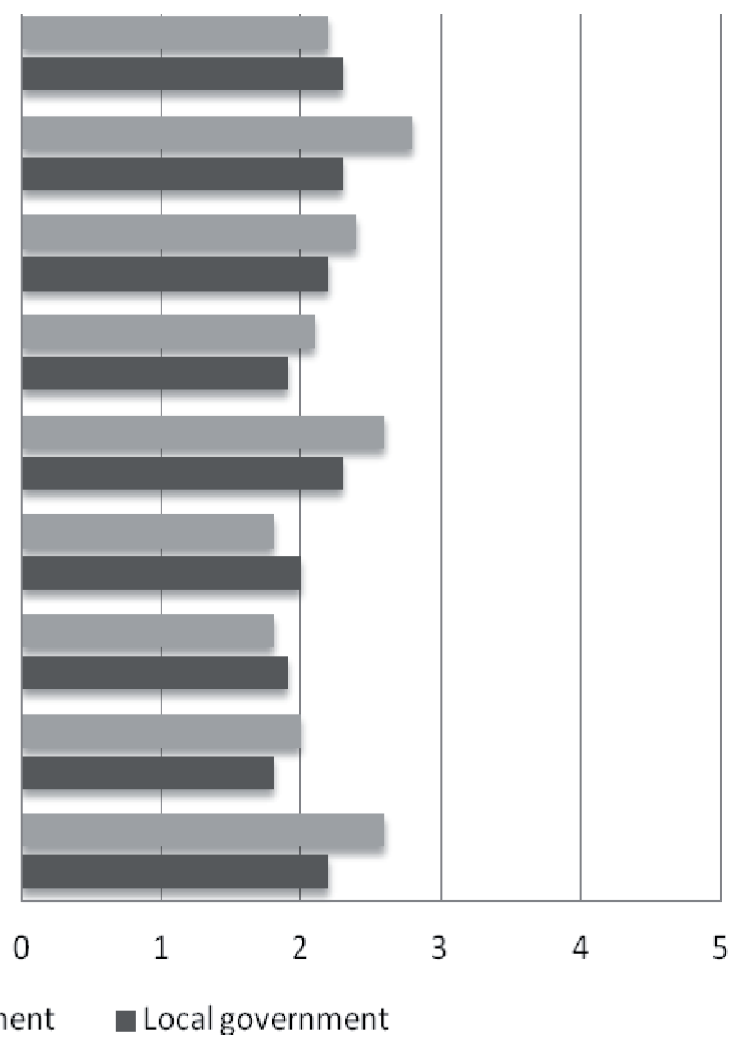

Figure 3. Cooperation with tourist enterprises

Consequently, the obtained results confirm the conclusions formulated in the previous research project regarding a high level of inertia of local institutional environment, wherein detailed findings provide an insight to the range and severity of that inertia from the innovation process perspective. According to the surveyed tourist firms the lack of funds for innovations and a high cost of innovative activities represent the most severely experienced barrier to innovations. Thus, the expectations directed towards institutional bodies are mainly concerned with direct financial support. Looking at the opposite site, transferring financial capital to business sector is one of the key tasks performed by local authorities, however those institutions are to serve as economic development facilitators and not as donators. Therefore, taking into account the aims of both sides, it is surprising that the supportive activity concerning providing knowledge and sharing best practices for raising funds to finance development ventures does not trigger collaborative attitudes among business and institutional entities. Undoubtedly, the ineffective information exchange accompanied by weak and scarce relations linking tourist enterprises and local institutions lead to a mismatch between the content of the supportive offer and the expectations of the potential 
recipients. In many cases tourist enterprises are not even aware of the variety of services and information they can benefit from.

The surveyed local institutions declared rather weak involvement in collaborative ventures aiming at developing new local tourist products. Such approach is quite contrary to the postulated function of the local authority as facilitator and incubator for generating common-destination innovative ideas. Thus, it is necessary to obtain an insight into the cooperation in innovation from the tourism business perspective. The findings presented in Figure 4 indicate that only a very tiny proportion of tourist enterprises cooperate with local institutional bodies at all three stages of the innovation process. According to the findings, a joint work of tourist firms and local institutions can be classified as an incidental phenomenon. What is more, the obtained results give evidence of a weak propensity towards collaboration with all types of potential partners (Najda-Janoszka, 2013a).

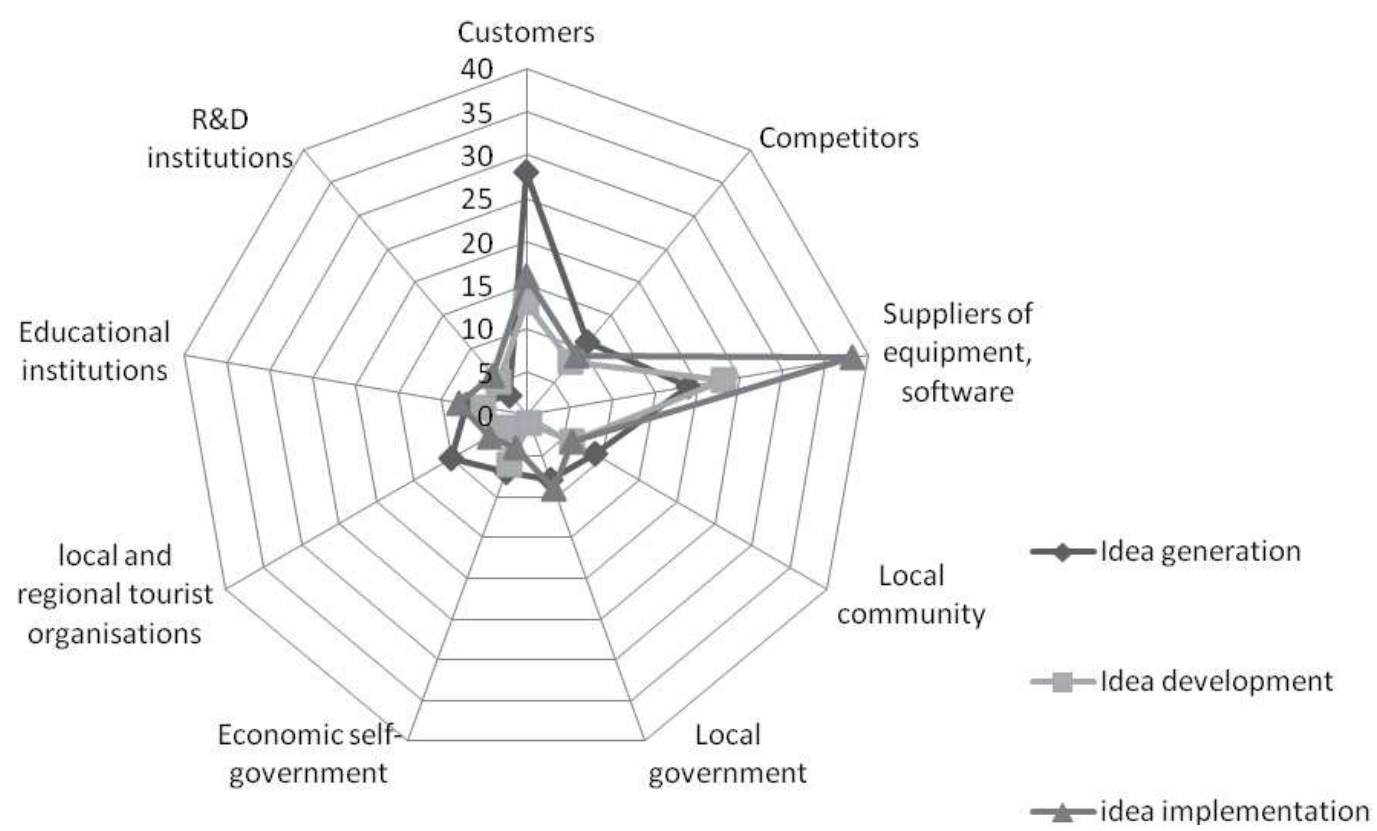

Figure 4. Cooperation in innovation

The "innovation collaborative profile" of investigated tourism enterprises overlaps their network of established business relationships together with the main channels of information exchange and the gained cooperative experience. Customers and suppliers of equipment and software represent the most welcomed partners for joint innovative activities. Given that tourism is commonly recognized as a customer oriented service industry, it is not surprising that tourist enterprises prefer to cooperate with clients while 
generating ideas for innovations. A shift towards suppliers in the next two stages of the innovation process can be justified by the fact that a great proportion of innovations introduced in tourism is supply-driven and in order to translate new ideas into final comprehensive solution tourist firms choose partners that provide the necessary specific and complex components. Yet, innovation in tourism is equally "an intrinsically territorial, localized phenomenon which is highly dependent on resources which are linked to specific places and are impossible to reproduce elsewhere" (Camison and Monfort-Mir, 2012, p. 782). Therefore, the fact that local community institutions remain at the margin of the innovation activity of the tourism business appears somehow paradoxical. Nevertheless, the lack of involvement in cooperation in innovation is exhibited by both sides, the business one and the institutional one. According to the findings tourist firms perceive local authorities rather as providers of financial support than potential partners having an attractive portfolio of valuable knowledge resources and capabilities. On the other side, the question is if local institutions are indeed aware of and experience the positive effects of innovative activity of tourism enterprises in a particular community or region.

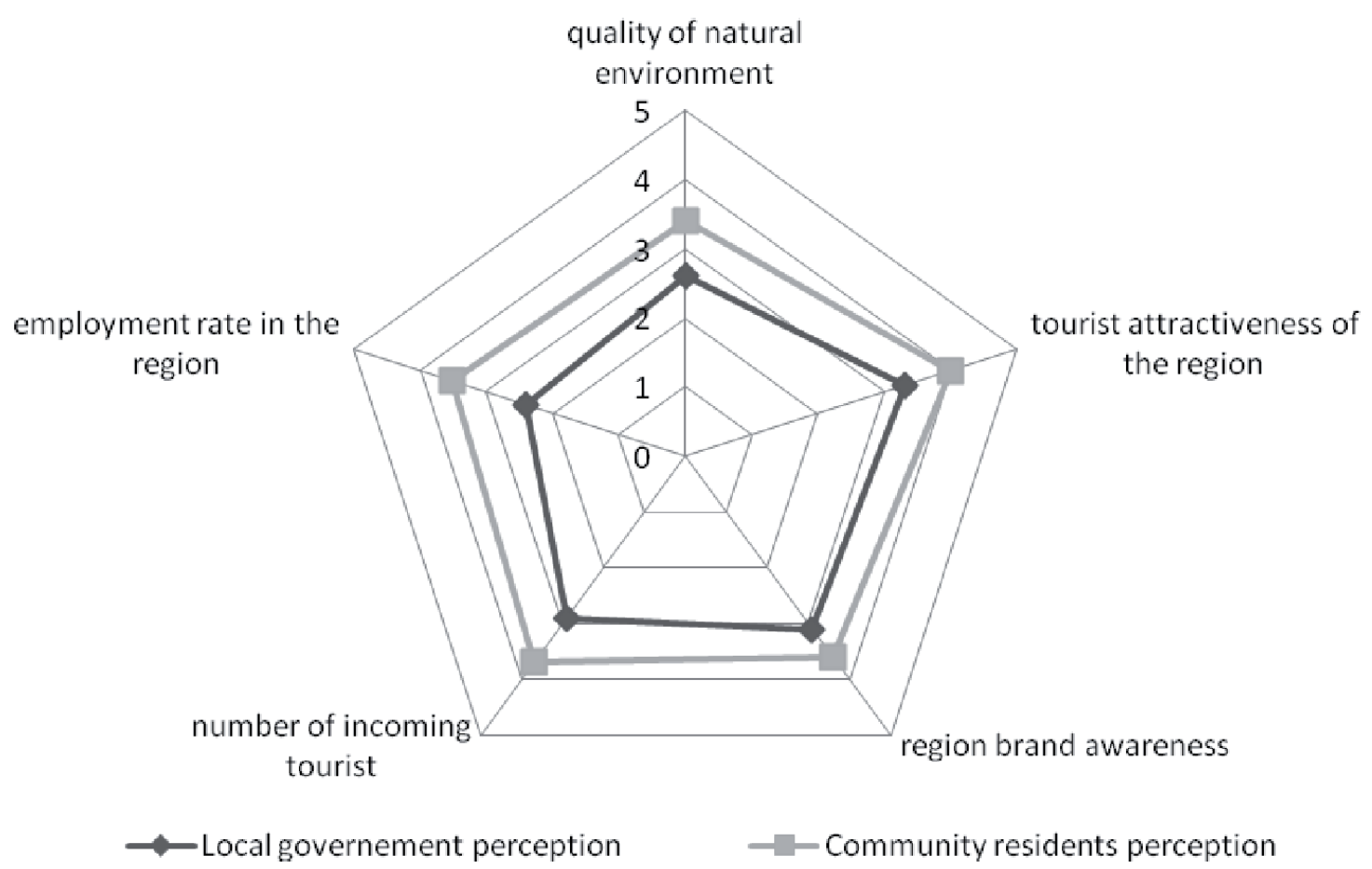

Figure 5. Effects of tourist innovation at regional level

As presented in Figure 5 from the local authorities perspective, the effects of innovation activity performed by tourism business are generally not 
spectacular. However, average and above average notes have been ascribed to the number of incoming tourists, tourist attractiveness of the region and region brand awareness - the cornerstones for the community development as a tourist destination (Kurleto et al., 2013). Interestingly, the community residents' perception of all indicated effects is more optimistic. The local communities as final beneficiaries of local economic development assess higher the innovative activity potential of tourism firms than institutions responsible for planning and implementing strategies for local development. Hence, given those key effects experienced by local communities and authorities, and the fact that tourism is officially recognized as one of the fastest growing economic sectors in the world and a key driver for socioeconomic progress, local institutional bodies responsible for providing favorable conditions for economic growth of the particular community should exhibit more interest in facilitating cooperative initiatives among tourism businesses operating in that community. According to the findings presented in the literature, the level of innovativeness is directly correlated with the cooperative activity (Trigo and Vence, 2012). Since many authors point at the weak propensity of tourism firms to cooperate in innovation due to the difficulties with protecting and appropriating value from innovations (Hjalager, 2002; Najda-Janoszka, 2013b), there is a great need for an efficient and effective intermediary agent to enhance the cooperative capability and further the innovation rate of tourist enterprises.

\section{Conclusion}

According to the open innovation model an effective strategy for increasing innovation and competitiveness of the region should be based on active and multilevel cooperation among operators of the local tourism business environment. An exceptionally important role in creating a favorable environment for the cooperative practices in the region is performed by local authorities. Results from the previous research project conducted in 2006-2009 pointed to a persistent high level of inertia of local institutional environment in creating conditions for the development of tourism business, as well as in facilitating cooperation among tourist enterprises. The consequences of that adverse level of inertia have been observed in the current study in various areas of the innovative value chain of the regional tourism. The local institutional bodies are considered of minor importance as sources of information for innovation, despite the fact that those institutions are assumed to perform an intermediary function in the knowledge transfer process within the tourism industry. Thus, the existing information exchange in the local tourism environment has not received high notes from tourist 
enterprises. Almost every second tourist firm indicates weak relations with the local authorities, hence, tourist business exhibits also weak propensity toward cooperation with those institutions.

The paucity of joint projects, initiatives, ventures, information-exchange makes it impossible for the investigated entities to develop specific competencies referred to as the ability to cooperate. The logical consequence of the inertia of local institutional bodies is marginal, often just incidental involvement in the innovation activity performed by tourism enterprises. Importantly, the lack of involvement in cooperation in innovation is exhibited by both sides, the business one and the institutional one. Given the negligible history of cooperation between tourism business and the local institutional environment, the main question concerns mutual expectations of the partiers and the perceived areas of possible cooperation. As local authorities are seen primarily as sources of direct financial support, it actually limits the partnership options. That in turn, according to the logic of the innovative value chain of the regional tourism and obtained results, affects the scale of experienced effects of innovations introduced by tourist business in particular region. Therefore, it is essential to develop an appropriate information policy directed toward tourist business, to promote and create awareness of all supportive activities performed by local institutions and possible areas of cooperation aiming at developing the tourist attractiveness of the region.

\section{References}

Batorski, J. (2013). Wewnętrzny łańcuch innowacyjności: zarządzanie wiedzą. In: Bednarczyk M. (Ed.) Zarzq̨dzanie innowacyjnym łańcuchem wartości turystyki regionalnej (report of research Project No. N 115321 339) Krakow: Jagiellonian University.

Bednarczyk, M. (2013). Podstawy metodyczne badań. In: Bednarczyk M. (Ed.) Zarzqdzanie innowacyjnym łańcuchem wartości turystyki regionalnej (report of research Project No. N 115321 339). Krakow: Jagiellonian University.

Bednarczyk, M. (Ed.) (2011). Zarzqdzanie konkurencyjnościq biznesu turystycznego w regionach. Warszawa: Wydawnictwo Fachowe CeDeWu.

Bednarczyk M. (Ed.). (2006). Przedsiębiorczość w gospodarce turystycznej opartej na wiedzy. Kraków: Fundacja dla Uniwersytetu Jagiellońskiego.

Blakely, E.J., Leigh, N.G. (2009). Planning Local Economic Development: Theory and Practice. USA California: Sage Publications Inc.

Camison, C., Monfort-Mir, V.M. (2012). Measuring innovation in tourism from the Schumpeterian and the dynamic-capabilities perspectives. Management in Tourism, 33(4), 776-789. 
Decelle, X. (2006). A dynamic conceptual approach to innovation in tourism. In: OECD, Innovation and Growth in Tourism (pp. 85-106). Paris: OECD, Paris.

Dziemianowicz, W. (2008). Konkurencyjność gmin w kontekście relacji władze lokalne - inwestorzy zagraniczni, Warszawa: Wydawnictwa Uniwersytetu Warszawskiego.

Hjalager, A.M. (2010). A Review of innovation research in tourism. Tourism Management, 31(1), 1-12.

Hjalager, A.M. (2002). Repairing innovation defectiveness in tourism. Tourism Management, 23(5), 465-474;

Keller, P. (2006). Innovation and tourism Policy. In: OECD, Innovation and Growth in Tourism (pp. 17-40). Paris: OECD, Paris.

Kopera, S. (2013). Wewnętrzny łańcuch innowacyjności: zastosowanie instrumentów technologii informacyjnej. In: Bednarczyk M. (Ed.) Zarządzanie innowacyjnym łańcuchem wartości turystyki regionalnej (report of research Project No. N 115321 339). Krakow: Jagiellonian University.

Kurleto, M., Chudzik, J., Marszałek, A. (2013). Zewnętrzny łańcuch innowacyjności: samorząd terytorialny i gospodarczy, społeczności lokalne, turyści oraz wsparcie finansowe. In: Bednarczyk M. (Ed.) Zarządzanie innowacyjnym łańcuchem wartości turystyki regionalnej (report of research Project No. N 115321 339). Krakow: Jagiellonian University.

Najda-Janoszka, M. (2013a). Współdziałanie małych i średnich przedsiębiorstw turystycznych w procesie innowacji i ochrona wytwarzanej nowej wartości. In: Bednarczyk M. (Ed.) Zarzq̨dzanie innowacyjnym łańcuchem wartości turystyki regionalnej (report of research Project No. N 115321 339). Krakow: Jagiellonian University.

Najda-Janoszka, M. (2013b). Zatrzymywanie wartości z innowacji w branży turystycznej. Współczesne Zarzqdzanie, 1(1), 96-105.

Najda-Janoszka, M. (2010). Instytucjonalne wsparcie przedsiębiorstw turystycznych na poziomie lokalnym w opinii przedsiębiorców. Problemy Zarządzania, 8(3), 48-62.

Nordin, S. (2003). Tourism Clustering \& Innovation - Paths to Economic Growth \& Development. Östersund: European Tourism Research Institute MidSweden University.

Sundbo, J., Orfila-Sintes, F., Sørensen, F. (2007). The innovative behavior of tourism firms - Comparative studies of Denmark and Spain. Research Policy, 36(1), 88-106.

Trigo, A., Vence, X. (2012). Scope and patterns of innovation cooperation in Spanish service enterprises. Research Policy, 41(3), 602-613.

Weiermair, K. (2006). Product improvement or innovation: What is the key to success in tourism? In: OECD Innovation and Growth in Tourism (pp. 53-69). Paris: OECD. 


\section{Abstrakt (in Polish)}

Zgodnie z otwartym modelem innowacji wzrost innowacyjności i konkurencyjności regionu powinien opierać się na aktywnej i wielokierunkowej współpracy między podmiotami lokalnego otoczenia biznesu turystycznego. W ramach literatury przedmiotu przyjmuje się, że niezwykle ważna rolę w tworzeniu środowiska sprzyjajqcego współdziałaniu w regionie pełniq lokalne instytucje. Jednakże, wyniki badań prezentowane $w$ literaturze wskazujq na dość wysoki poziom inercji władz lokalnych w tworzeniu warunków dla rozwoju branży turystycznej, tym samym stawiaja pod znakiem zapytania skuteczność realizacji przez te instytucje funkcji pośrednika w procesie transferu wiedzy między przedsiębiorstwami turystycznymi. Biorq̨c pod uwagę niedostatek badań weryfikujqcych efektywność polityki innowacyjnej na poziomie regionalnym, w niniejszym artykule przedstawiono wyniki badań empirycznych dotyczq̨cych wspótpracy pomiędzy przedsiębiorstwami turystycznych i lokalnymi instytucjami w zakresie działalności innowacyjnej.

Słowa kluczowe: turystyka, innowacyjność, kooperacja, otoczenie instytucjonalne, samorzqd lokalny. 